\title{
STUDIES IN WILD SPECIES OF COTTON
}

\section{VARIATION WITHIN GOSSYPIUM ANOMALUM}

\author{
J. H. SAUNDERS \\ Empire Cotton Growing Corporation and Research Division, \\ Sudan Ministry of Agriculture
}

Received 9.vii. $5^{8}$

\section{INTRODUCTION}

Gossypium anomalum Wawra and Peyr is a wild diploid cotton indigenous to the African continent. It lacks spinnable lint having only a short khaki fuzz appressed to the seed. This species and $G$. somalense have been collected in natural vegetation in the Sudan, and their distribution in that country has been described by Knight (1949). A botanical description of $G$. anomalum was published by Hutchinson, Silow and Stephens (1947).

One accession only of $G$. anomalum has been extensively studied. This work was carried out by Silow (194I) who investigated the comparative genetics of $G$. anomalum and the Asiatic cottons. The type he used represents the most widely known form of the species and is maintained under the number WBI-I. At the present time I 5 accessions of anomalum are grown at Shambat, near Khartoum, in the northern Sudan. These represent the following areas: I from W. Africa (WBI-I), Io from different districts of the Sudan and 4 from southern Africa.

The 15 types are grown perennially in the collection of wild species. The most striking feature of these representatives of anomalum from widely separated areas is their remarkably uniform appearance. Small differences are discernible in habit; there is some variation in boll shape; the southern types flower somewhat later than the northern accessions and 3 of the 4 southern types have a magenta flower colour, the northern all being cream. Only one glabrescent anomalum has been found and this was collected in the south. One accession from the Sudan was found to possess a distinct leaf shape.

Because the variation within anomalum described above has so far not been reported, this study was carried out. The genetics of flower colour, leaf shape and hairiness will be discussed here.

\section{MATERIALS AND METHODS}

The strains of $G$. anomalum used in this study were :

WBI-I : Densely hairy on all parts of the leaf and stem; pale cream flower sometimes tinged with anthocyanin; $\frac{3}{4}$ cut leaves usually 5 -lobed. Collected in W. Africa.

WBI-5: Differs from WBI-I only in that the leaves are about $\frac{1}{3}$ cut into 3 broad lobes. Collected in the Sudan.

WBI-I4: Magenta-coloured flower; glabrescent leaves and plant body. Leaf shape similar to $\mathrm{WB}_{\mathrm{I}-\mathrm{I}}$. Collected in S.W. Africa. 
WBI-5 and $W_{1-14}$ were crossed with $W B_{1-1}$ and $F_{2}$ and $F_{3}$ familics were raiscd. The results will be given below.

The sccds of anomalum possess a very hard testa and becausc of this seeds germinate very erratically under ordinary conditions of cultivation. All secds were therefore chipped, germinated on damp filter paper and raiscd as seedlings in a greenhousc for later planting in the field.

Cotton flowers are selfed at Shambat by clipping a small endrin-impregnated paper bag over the unopened flower. A poor set was obtained with anomalum treated in this way and the $\mathbf{F}_{2}$ families were small in consequence. This difficulty was overcome by removal of the bag at the time when the flower had opened for mechanical application of self pollen to the stigma with subsequent rcplaccment of the bag. When this was done a satisfactory boll setting was obtained.

\section{RESULTS}

(i) Flower colour

Flower colour was graded by eye estimation and five grades were used ; a description follows :

\begin{tabular}{|c|l|l|}
\hline Grade & \multicolumn{1}{|c|}{ Description } & Parents and Hybrids \\
\hline I & $\begin{array}{l}\text { Pale cream } \\
\text { Pale cream tinged pink }\end{array}$ & $\begin{array}{l}\text { WBI-1 } \\
\text { range }\end{array}$ \\
\hline 3 & $\begin{array}{l}\text { Weak magenta } \\
\text { Moderate magenta }\end{array}$ & $\begin{array}{l}\text { WB1-1 } \\
\text { range }\end{array}$ \\
\hline 5 & Strong magenta & Hybrid segregates only \\
\hline
\end{tabular}

Nine $F_{I}$ plants were grown from the cross WBI-I (cream) $\times$ WBI-I 4 (magenta). Although a note was made that this $F_{1}$ was a light magenta colour no grade was recorded since at that time the cross was intended solely for a study of hairiness. From these nine plants $\mathrm{F}_{2} \mathrm{~s}$ were grown.

It was decided in 1956 that these families should be used for a study of corolla colour inheritance. At the end of the season it was realised that the method of grading colour was unsatisfactory and that the assessment of tones in the bright glare of the sun could be subject to considerable error.

One entire $F_{2}$ family $\mathrm{G}_{23} 33 / 56$ was individually selfed and the resultant $\mathrm{F}_{3} \mathrm{~s}$ raised in 1957 . Colour assessment was made on flowers brought into the laboratory and examined at a well-lit window out of the glare of the sun. The parent types were always available for comparison. It was found that by using this method flowers could be placed with complete confidence into one or another of the grades I to 5 . The results are set out in table $\mathrm{I}$.

Differences in flower colour grade can be due to both genetic and environmental influences. Silow (I94I) recorded variability of anthocyanin expression within plants and explained this as being due to differences in exposure of flower buds to the sun. The writer has 
repeatedly observed flowers of differing grades upon the same plant. This being the case, family grading based upon one flower per plant can obviously be subject to error, but this error has to be accepted since replication of flower colour assessment was not a practicable measure in view of the amount of work involved. Since this type of error can equally well occur in all families, differences in mean grade are more likely to be due to genetic causes.

A complete understanding of the nature of corolla colour inheritance within anomalum would require considerably more extensive study

TABLE I

$F_{3}$ families from the cross $W B_{I-I} \times W B_{I-I 4}$

\begin{tabular}{|c|c|c|c|c|c|c|c|}
\hline \multirow{2}{*}{$\begin{array}{l}\text { G Family } \\
\text { I } 957\end{array}$} & \multicolumn{5}{|c|}{ Colour Grades } & \multirow{2}{*}{ Total } & \multirow{2}{*}{$\begin{array}{l}\text { Mean } \\
\text { Grade }\end{array}$} \\
\hline & I & 2 & 3 & 4 & 5 & & \\
\hline $\begin{array}{l}\mathrm{WBI}-\mathrm{I} \\
\mathrm{WBI}-\mathrm{I} 4\end{array}$ & $\begin{array}{l}\cdots \\
\cdots\end{array}$ & 7 & $\begin{array}{l}\ldots \\
23\end{array}$ & I9 & $\begin{array}{l}\cdots \\
\cdots\end{array}$ & 49 & $\begin{array}{l}\mathrm{I} \cdot 5 \\
3 \cdot 2\end{array}$ \\
\hline $\mathrm{G}_{222 / 57}$ & 33 & 2 & 2 & $\ldots$ & $\ldots$ & 37 & $I \cdot 2$ \\
\hline 220. & $3^{6}$ & 22 & $\ldots$ & $\ldots$ & $\ldots$ & $5^{8}$ & $1 \cdot 4$ \\
\hline 228 & 24 & 7 & 3 & $\ldots$ & $\ldots$ & 34 & $I \cdot 4$ \\
\hline 217. & 54 & 46 & 3 & $\ldots$ & $\ldots$ & 103 & $I \cdot 5$ \\
\hline 219. & 23 & 22 & I & $\ldots$ & $\ldots$ & 46 & $1 \cdot 5$ \\
\hline & 47 & 73 & IO & $\ldots$ & $\ldots$ & 130 & $1 \cdot 7$ \\
\hline 223 & I 8 & 17 & Io & I & I & 47 & $1 \cdot 9$ \\
\hline 227 & 37 & 47 & 26 & I & $\cdots$ & III & $I \cdot 9$ \\
\hline $22 \mathrm{I}$ & $3^{\circ}$ & 39 & $2 I$ & 3 & $\ldots$ & 93 & $2 \cdot 0$ \\
\hline & 7 & 30 & $2 \mathrm{I}$ & 19 & ... & 77 & $2 \cdot 7$ \\
\hline 224. & 3 & 8 & 46 & 22 & I & 80 & $3 \cdot 1$ \\
\hline 226 & $\ldots$ & 7 & 20 & 62 & 2 & $9^{I}$ & $3 \cdot 6$ \\
\hline
\end{tabular}

than it has been possible to give it here. However, the data presented shows more variation than would be expected if the control of colour was monogenic. This clearly points to polygenic influence on the intensity of pigmentation.

\section{(ii) Leaf shape}

The leaf-shape gene normally encountered in anomalum was given the symbol $L^{A}$ by Silow (1939) who found that it was a member of a multiple allelic series for leaf shape in the Asiatic cottons. He used two indices to record leaf shape, they were:-

$$
\begin{aligned}
& \text { Index } \mathrm{G}=\frac{\text { Sinus Length }}{\text { Leaf Length }} \\
& \text { Index } \mathrm{D}=\frac{\text { Lobc Width }}{\text { Leaf Length }}
\end{aligned}
$$

These indices are reciprocals of those used in earlier studies on the cotton leaf made by Hutchinson (1934) and are used in the work reported here. Indices are $\times$ roo eliminating decimals. 
$L^{A}$ is the leaf-shape gene of $\mathrm{WB}_{\mathrm{I}-\mathrm{I}}$, a $\frac{3}{4}$ cut palmatifid leaf of 5 lobes (fig. I $a$ ). WBI-5 has a lcaf $\frac{1}{3}$ palmately cut and is 3 -lobed (fig. I $b$ ). In 1956 nine plants from a bulk cross between WBI-i and WBI-5 were grown and sclfed. The $F_{2}$ familics were grown in the season 1956/57. Of these only four segregated for leaf shape, the remainder being homozygous for the $L^{A}$ gene. It was realised later that the WBI-5 stock which is grown perennially at Shambat was not pure for the leaf-shape allele under study and that some plants heterozygous for this gene and $L^{A}$ were crossed to WBI-I $\left(L^{A} L^{A}\right)$ to produce the $\mathrm{F}_{\mathrm{I}}$ which was thus mixed and hence gave the nonsegregating families in $\mathrm{F}_{2}$. The families which did segregate gave 20 to 6, I 6 to 4,5 to 5 and 4 to 5 palmatified $L^{A}$ types to palmate types. The two largest families suggest monofactorial segrcgation. In vicw of the small $F_{2}$ family numbers it was necessary to grow an

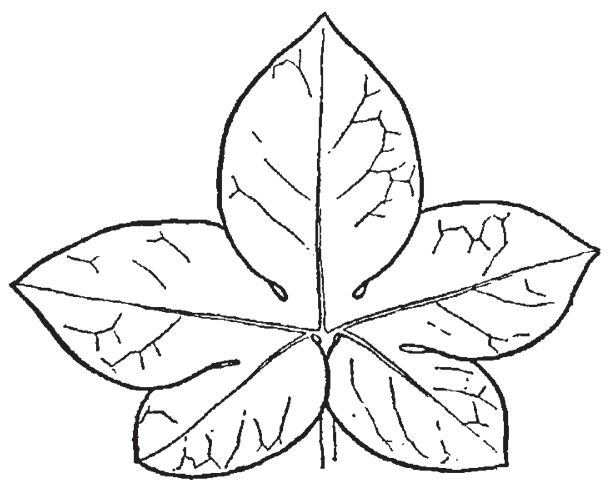

Fig. Ia.-Palmatifid.

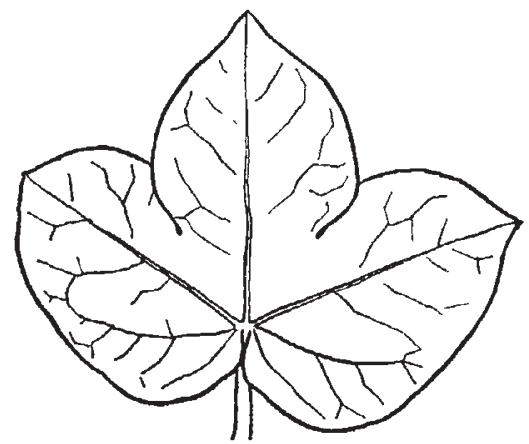

Fig. I $b$. -.Palmate.

adequate number of $\mathrm{F}_{3} \mathrm{~s}$. Onc family G243/56 (giving the ratio 20 to 6 mentioned above) was entirely individually selfed with the exception of two rather weak plants, so leaving the family effectively as I 9 to 5 . The resulting $F_{3}$ families are set out in detail in table 2 . Without exception the seven families segregating for the shape genes show exccllent approximations to $3:$ i expcctations, thus confirming the indication given in the $\mathrm{F}_{2}$ families that a single locus is involved.

It is of interest to note here that the family $\mathrm{G}_{243} 45^{6}$ with an observed 20 dominants to 6 recessives, which is an excellent fit to a $3: \mathrm{I}$, is in fact spuriously so when the $\mathrm{F}_{3}$ data are examincd. Table 2 shows that 12 of the $F_{2}$ plants must have been homozygous palmatifid, 7 heterozygous and 5 homozygous palmate allowing for the two plants which did not bear seed. This is in poor agrccment with an expected $6:$ i $2: 6$.

The data for the scven segregating families have been combined and index $\mathrm{C}$ plotted against index $\mathrm{D}$ in table 3 . It can be readily seen that the real difference between palmatifid and palmatc lies in sinus length, lobc width hardly diffcring at all. Stcphens (1944) when comparing $L^{A}$ and $\boldsymbol{I}$ found that the difference lay in sinus length 
and came to the conclusion that $L^{A}$ ". . . has an extremely localised effect in the sinus region of the leaf".

The gene for palmatifid is incompletely dominant over that for palmate leaf. Table 3 shows that the palmatifid homozygote and the

TABLE 2

$F_{3}$ families from the cross $W B_{I-I} \times W B_{I-5}$

\begin{tabular}{|c|c|c|c|c|}
\hline \multirow{2}{*}{$\begin{array}{l}\text { Parent } \\
\text { genotype }\end{array}$} & \multirow{2}{*}{$\begin{array}{c}\text { G Family } \\
1957\end{array}$} & \multicolumn{3}{|c|}{ Observed } \\
\hline & & Palmatifid & Heterozygore & Palmate \\
\hline Palmatifid & $\begin{array}{l}229 \\
234 \\
235 \\
237 \\
238 \\
239 \\
245 \\
246 \\
247 \\
248 \\
249 \\
25^{I}\end{array}$ & $\begin{array}{l}14 \\
32 \\
32 \\
31 \\
31 \\
45 \\
71 \\
69 \\
80 \\
57 \\
45 \\
41\end{array}$ & $\begin{array}{l}\ldots \\
\ldots \\
\ldots \\
\ldots \\
\ldots \\
\ldots \\
\ldots \\
\ldots \\
\ldots \\
\ldots \\
\ldots \\
2\end{array}$ & $\begin{array}{l}\ldots \\
\cdots \\
\cdots \\
\cdots \\
\cdots \\
\cdots \\
\cdots \\
\cdots \\
\cdots \\
\cdots \\
\cdots \\
\cdots\end{array}$ \\
\hline Heterozygote & $\begin{array}{l}230 \\
23^{\circ} \\
24^{\circ} \\
24^{2} \\
244 \\
25^{\circ} \\
25^{2}\end{array}$ & & & $\begin{array}{r}8 \\
20 \\
10 \\
2 \\
14 \\
17 \\
15\end{array}$ \\
\hline Palmate & $\begin{array}{l}23 I \\
233 \\
236 \\
241 \\
243\end{array}$ & $\begin{array}{l}\ldots \\
\cdots \\
\cdots \\
\cdots \\
\cdots\end{array}$ & $\begin{array}{l}\cdots \\
{ }_{1} * \\
\cdots \\
\cdots \\
3 *\end{array}$ & $\begin{array}{r}81 \\
39 \\
33 \\
5 \\
33\end{array}$ \\
\hline
\end{tabular}

* Possible outcrosses.

heterozygote merge into one another in respect of the indices but are distinctly separate from the palmate homozygote. In corrclation tables for individual families this separation is much more marked, but in bulking the data for table 3 family differcnces blur the distinction. All heterozygotes had a higher value for index $\mathrm{C}$ than the homozygotes although this distinction was not marked enough for confidence in placing them in a separate class. Thus the type of dominance found here is in agreement with the field series of Hutchinson (1934), i.e. dominance is in the direction of deep-cut leaves.

Modifier control over lobe width has been noted in previous leafshape studies (Silow, I939). Evidence of a lobe width modifier will be presented here also. If the mean values for $\mathrm{C}$ and $\mathrm{D}$ for each of the segregating families are plotted in such a way that each family 


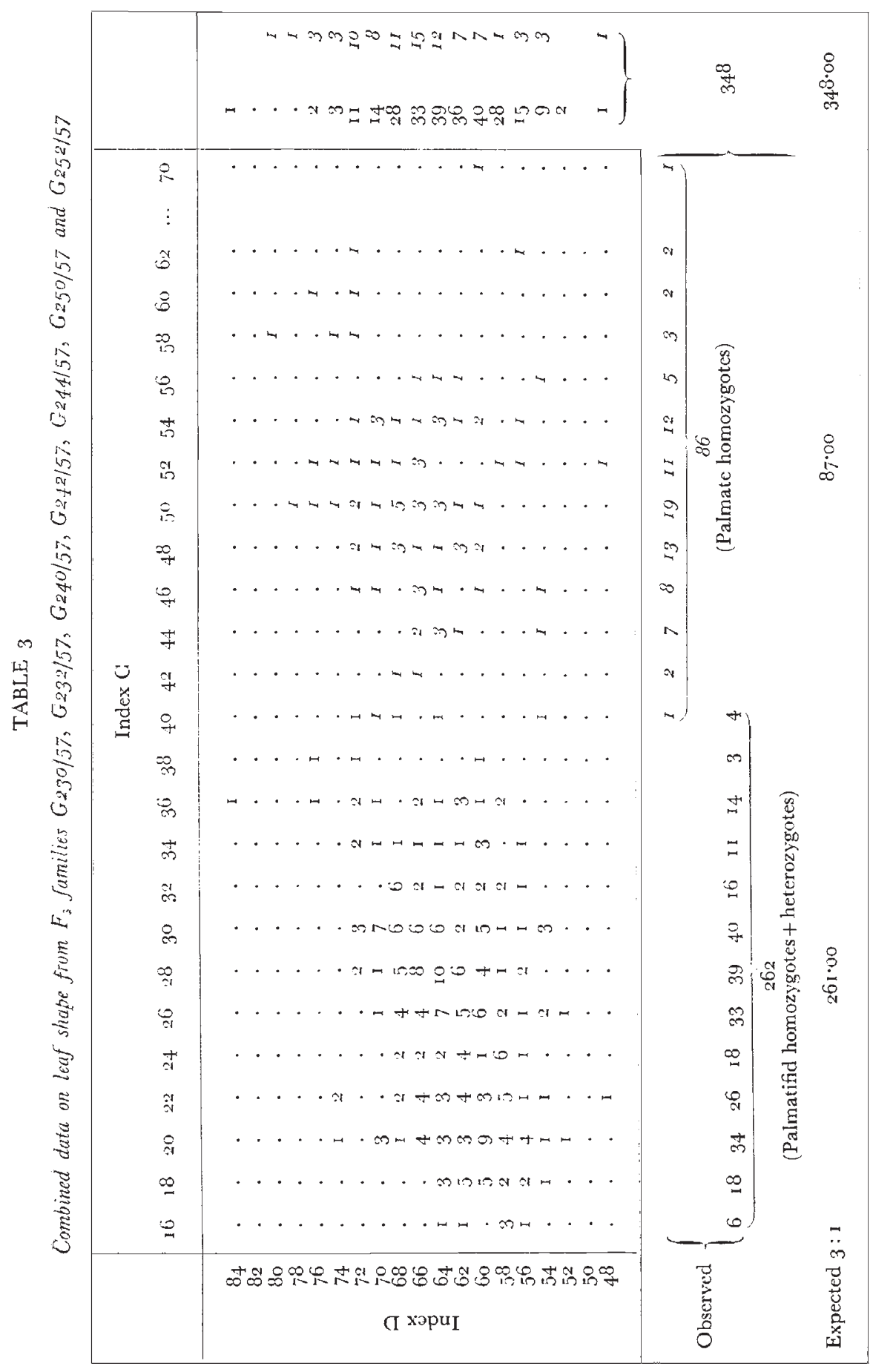


has two means, one for the dominant group and one for the recessive group and these two values joined by a line, this line then acts as a pointer to the related values and also defines the slope between them. The seven families are then seen to fall into three distinct groups (see fig. 2) and these groups are in the proportions $2: 3: 2$. A further point emphasising the reality of this grouping is the noticeably different slope of the lines of the middle group, all of which are similar within the group. The two outside groups are similar to each other in slope.

These findings can be interpreted as being due to a modifier $M$ which increases the $\mathrm{W} / \mathrm{L}$ value; $m m$ causes no change and $M m$ is intermediate in value between this and $M M$. In fig. $2 \mathrm{G}_{230 / 57}$ and

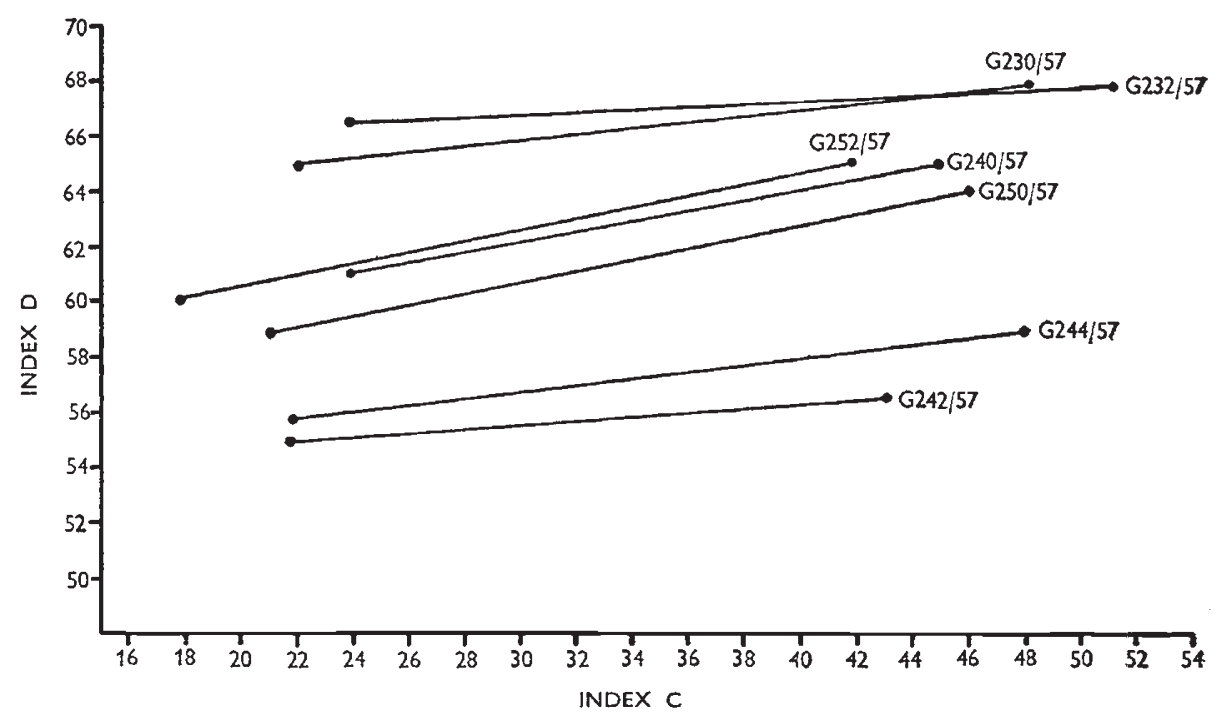

Fig. 2.-Each family is represented by two means joined by a line indicating the slope between the means. The group at the lower end of index $\mathrm{C}$ is Palmatifid heterozygotes and the group at the higher end of index $\mathrm{C}$ is Palmate.

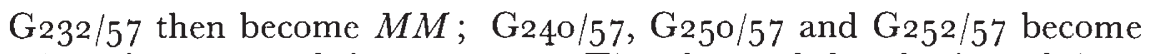
$\mathrm{Mm} ; \mathrm{G}_{242 / 57}$ and $\mathrm{G}_{244 / 57} \mathrm{~mm}$. The observed distribution of these groups of $2: 3: 2$, while in reasonable agreement with an expected I : $2:$ I, cannot be taken as reliably establishing the existence of the modifier because of the small number of families. If this modifier is acting here it is of interest to note that when heterozygous $(\mathrm{Mm})$ it acts unequally upon the palmatifid and palmate classes so giving the difference in slope observable between the middle group and the others. Silow (1939) drew attention to modifiers which acted differentially upon the three phases of a main gene. The homozygous broad leaf was made even broader, the heterozygote broader to a lesser extent and the homozygous narrow leaf hardly affected at all. The differential here appears to be in the heterozygous phase of the modifier but the effect is similar to Silow's findings in that the broad leaf is made even broader and that the narrower allele is affected to a slightly less extent. 
The effect of this modifier upon the homozygous families is observable but not easily analysable sincc the distribution is continuous, the heterozygotic families are simpler because of the use that can be made of the angle of slope joining the dominant and recessive groups.

\section{(iii) Hairiness}

The two accessions studied may be described with respect to hair as follows :-

(a) WB1-1: strongly hairy with dense soft hair on both leaf surfaces, mocicrate length. Densely hairy on all vascular tissues with hair at two levels. Long simple single or double hairs dominant; the sccond level stellate hairs, eight or more arms, not more than half the length of the simple hairs and considerably less dense.

(b) WBI-I4: distribution of hair the samc as for WBI-I but with the absence of long simple hairs from the vascular tissues. Hair very sparsc on all surfaces and hence described as glabrescent.

In an analysis of the hairiness of WBI-I, it would be desirable to cross it with a fully glabrous anomalum but no such strain has becn rccorded and the glabrescent WBI-I4 was therefore used. The $F_{1}$ was found to bc only slightly more hairy than the glabrescent parent. Fully hairy appeared to be reccssive and this was confirmed in later work.

Grading for hairiness was donc in the ficld on one leaf per plant. The first fully expanded leaf was used at about the commencement of flowcring. Because of the two-level hairiness it was necessary to grade for both length and density. Grades o-8 were used for density and grades I-8 for length. Four surfaces were examined, lower leaf lamina, upper leaf lamina, stem or petiole and upper main vcin surfaces. Studies on hairiness in cotton have been in progress at Shambat for some time and it has been found neccssary to include all these surfaces for an adequatc analysis of the inheritance of hairiness.

Since the classes "Fully Hairy" and "Glabrescent + Slightly Hairy" are unmistakably distinct the data will not be presented under the grades recorded in the field but grouped under these hcads.

The small $F_{2}$ families gave very little guidance as to the true nature of the segregation. However, the bulked data (26 Fully Hairy to 64 Glabrescent) suggest a single gene difference between dense and very sparse hair.

The $F_{3}$ familics leave no doubt that this interpretation is justified. The entire $F_{2}$ family $G_{23} / 5^{6}$, segregating I glabrescents to 2 fully hairiness, was individually selfed and the results are presented in table 4 .

Of the I I glabrescents in $\mathrm{G} 233 / 5^{6}, 3$ were found to be homozygous glabrescent, 7 scgregated for hair and onc produced no seed, the 2 fully hairies brecding true. Thus $\mathrm{G}_{233} / 5^{6}$ gave 3 homozygous glabrescents, 7 heterozygous hairiness and 2 fully hairies. This is in good agreement with an expectation of $3 \cdot 0,6 \cdot 0$ and $3 \cdot 0$ for the same classcs for a $\mathrm{I}: 2$ : $\mathrm{x}$ ratio. In most segregating families (scc table 4 ) 


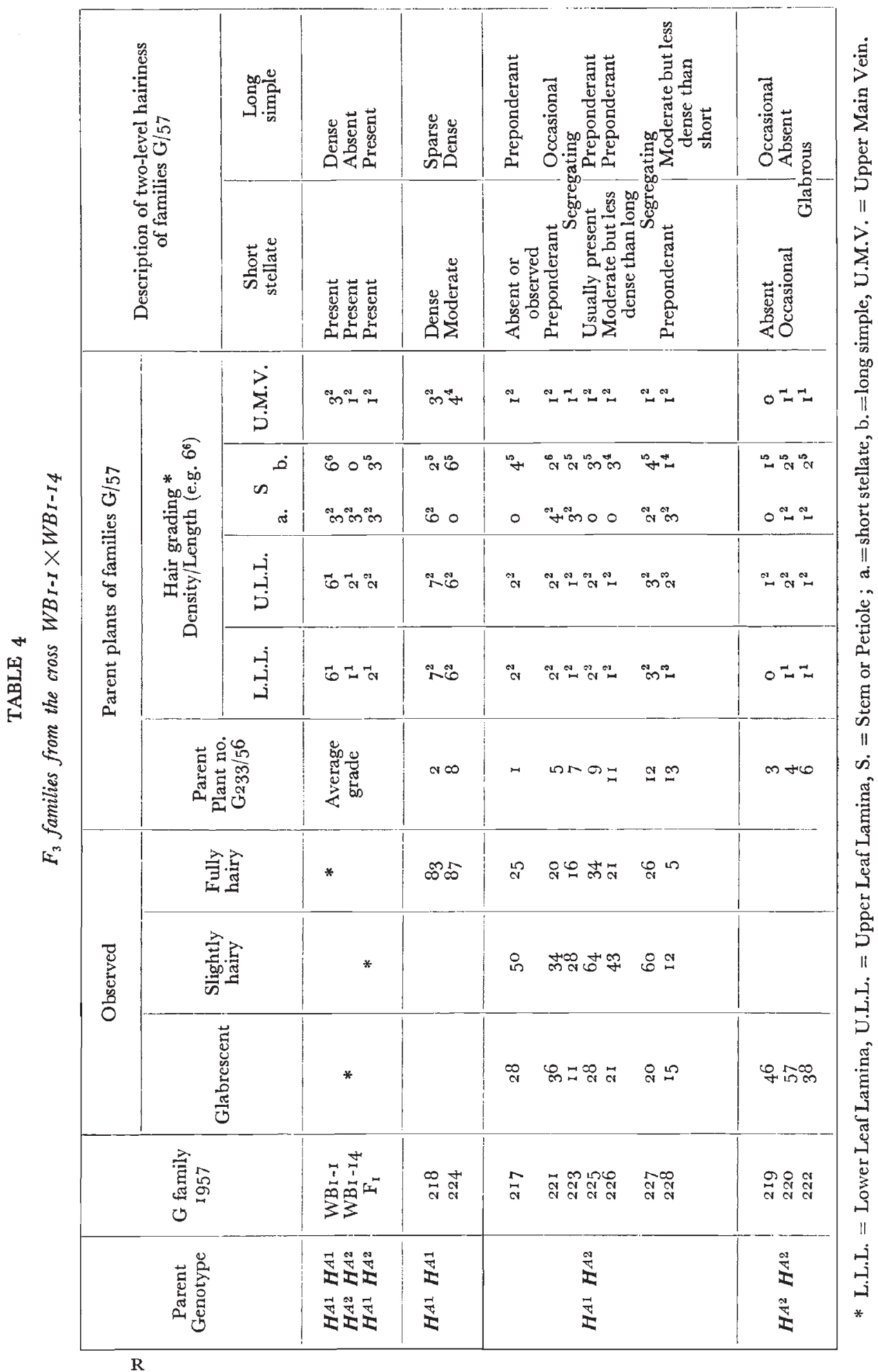


it was possible to place plants into cach of the threc classes, but in two families, G22 I/57 and G228/57 glabrescent and slightly hairy were too close in phenotypc for accuracy in separating the two classes. There was of course no doubt at any time concerning the fully hairy class. The figures require no comment since in all cases the agreement with expectation is cxcellent. Sparse hair and dense hair are therefore due to allclic genes and the following symbols are proposed, $\boldsymbol{H}^{A \mathrm{I}}$ for the densely hairy condition of $\mathrm{WBI-I}$ which is recessive to $H^{A 2}$, the sparscly hairy condition of $\mathrm{WBI}-14$. This scheme allows for the possibility of other alleles at the same locus being discovered. However, a revision may be necessary should it be possible to test the homology of this locus with those of the New World or Asiatic cottons.

TABLE 5

$F_{2}$ and $F_{3}$ families of the cross $W B_{I-I} \times W B_{I-14}$

\begin{tabular}{|c|c|c|c|c|c|c|c|}
\hline & & $\begin{array}{r}\text { Bulk o } \\
\mathrm{G}_{23} \\
\mathrm{G}_{2}\end{array}$ & $\begin{array}{l}\text { families } \\
15^{6} \text { to } \\
1 / 56\end{array}$ & & $3 / 57$ & & $7 / 57$ \\
\hline & & Frairy & $\begin{array}{l}\text { Glabre- } \\
\text { scent }\end{array}$ & Hairy & $\begin{array}{l}\text { Glabrc- } \\
\text { scent }\end{array}$ & Hairy & $\begin{array}{l}\text { Glabre- } \\
\text { scent }\end{array}$ \\
\hline Long simplc preponderant & Observed & 7 & 23 & 8 & 7 & 6 & 25 \\
\hline $\begin{array}{l}\text { Long simple/short stellate } \\
\text { No preponderance }\end{array}$ & Observed & I 3 & 26 & 2 & 26 & 10 & 47 \\
\hline Short stellate preponderant & Observed & 6 & 14 & 6 & 6 & 9 & 9 \\
\hline Totals. & Obscrved & 26 & 63 & ${ }_{16} 6$ & 39 & 25 & $8 x$ \\
\hline
\end{tabular}

WBI-I and WBI-I4 differed also in one other respect with regard to hair. WBI-I possessed two levels of hairiness on the vascular tissues and WBI-I4 only onc. An examination of the grading for length and density of stem hair showed that this condition was under apparently simple control, i.e. a single factor determines the relative amounts of long simple hairs and short stellate ones on the stem and petiole. The data were divided into three classes where scgregation for this factor was occurring. These classes were, I. long simple hairs preponderant, stcllate sometimes absent, 2. long simple and short stellate present in approximately equal densities and 3 . short stellate preponderant, long sometimes absent. Thesc classes corresponding to what might be expected to be found from the action of gene pairs $A A, A a$ or $a a$ respectivcly on the $H^{A}$ locus. All families showing variation for this character werc plotted against segregation for hair density due to $\boldsymbol{H}^{A 1}$ and $\boldsymbol{H}^{A 2}$ (see table 5 ).

The bulked figures for the $\mathrm{F}_{2}$ families give a very good agrecment indeed with the expectation for independent segregation of two 
factors except in the Long-equal/Glabrescent section. Here difficulties in grading glabrescents are thought to be contributory causes leading to error. Jointly long plus equal give a good 3: I to short. G223/57 and G227/57 show large discrepancies at certain points in the tables but the individual $3: \mathrm{I}$ and $\mathrm{I}: 2:$ I ratios are good. It is felt that in spite of the discrepancies there is very good evidence for the independent action of a gene affecting the two-level character of stem hair. The nature of the stem hair in those families not segregating for this character is noted in table 4, giving further evidence of its action. This modifier shows no dominance and its mode of action could be that of a suppressor controlling the production of a certain substance which determines the relative amounts of each hair type grown. The symbol proposed for this gene is therefore $S u^{h}$, i.e. hair suppressor, and represents the type found in WBI-I, namely, dominant long simple hairs, short stellate sparse or absent. It follows that $s u^{h}$ represents dominant short stellate, long simple sparse or absent as in $\mathrm{WBI}-\mathrm{I} 4$.

\section{DISCUSSION}

Two new genes have been described for $G$. anomalum and a preliminary investigation into flower colour made. Apart from this variation the species is remarkably uniform. The extremely wide distribution of $G$. anomalum, stretching across the entire width of Northern Africa and occupying the S.W. of Southern Africa but discontinuous between these areas, might lead one to expect greater divergencies than are actually found. Since the natural habitat of the plant is extremely xerophytic each small group of wild plants is often separated from others by great distances. This is particularly true of the Sudan where as few as one or two plants may occupy a stony Jebel separated from the next Jebel by many miles of arid desert; thus the isolation of plants within the distribution is quite marked.

If a more intensive study were possible it is quite likely that plants collected from different localities, in particular those from the south in comparison with those from the north, would show differences in genetic balance due to selective response to locality. This is perhaps indicated in disturbances noticed in flower structure in the $\mathrm{F}_{3}$ material from the cross between the northern WBI-I and the southern WBI-I4. The flowers of the parent strains, apart from colour, are identical, yet the hybrid material contained minutely petalled flowers, short corollas which did not open and from which the stigmas protruded, and lastly petalody.

Two other magenta-flowered accessions exist in the collection, both from the S.W. However, it is not known whether the flower colour mechanism within these is similar to WBI-I. No magentaflowered anomalum is known in the north.

Wagner and Mitchell (r 955) discuss very fully the types of modifiers reported in the literature. They say, "Many intermediate conditions exist which lie between the extreme examples of suppressor and complementary genes on the one hand, and genes which seemingly produce 
their phenotypic effect completely independently of all other genes, on the other hand. Most of the intermediate types are best described by the general term modifiers. . .." If the genotype acts as a coordinated whole, which presumably it must, then all genes are to some extent modifiers of one another-these effects are not readily obscrvable except when the genotypic balance is disturbed by hybridization as is the case in the examples noticed here. The modification of the main gene type may have no significance beyond an indication of a disturbed genotypic balance which is ascribable to a unit gene or block of gencs.

\section{SUMMARY}

I. Attention has been drawn to the uniformity of the species $G$. anomalum despite its cxtremely wide range and isolation within that range.

2. No final conclusions could be drawn about the genetics of flower colour. It was thought that at least one genc of large cffect was present operating against a polygenic background which gives a wide range of colour types in hybrid populations.

3. A single gene difference between palmatifid and palmate leaf shape is described. Since the relationship with Silow's $L^{A}$ has not becn studied, no symbol is assigned to the new gene for palmately cut leaf. Evidence is presented for the existence of a gene affecting lobe width.

4. The hairiness of $G$. anomalum is basically due to control at a single locus. Dense hairiness is reccssive to very sparse hairiness and the symbols $H^{A 1}$ and $H^{A^{2}}$ have been given to these conditions respectively. The two-level hairiness of the stem and petiole is clearly under monogenic control. This gene $S u^{h}$, has been so called because of its suppressor-type action.

5. The significance of the occurrence of modifiers was discussed.

Acknowledgment.-My thanks arc due to Professor Sir Joseph Hutchinson for reading the manuscript and giving helpful criticism.

\section{REFERENCES}

Hutchinson, J. B. I934. The genetics of cotton. X. The inheritance of lcaf shape in Asiatic Gossypiums. 7. Genet., 28, 437-5 I3.

HUTGHinson, J. B., SiLOW, R. A., AND STEPHFNs, s. G. I947. The Evolution of Gossypium. Oxford Press.

KNIGHT, R. L. 1949. The distribution of wild species of Gossypium in the Sudan. Emp. Cott. Gr. Rev., 26, x-8.

siLow, R. A. I939. The genetics of leaf shape in diploid cottons and the theory of gene interaction. 7. Genet., 38, 229-276.

sirow, R. A. I94I. The comparative genetics of Gossypium anomalum and the cultivated Asiatic cottons. 7. Genet., 42, 259-358.

STEPHENS, S. G. 1944. The genetic organization of leaf-shape development in the genus Gossypium. 7. Genet., 44, 28-5x.

WAgner, R. P., AND mitchel.t, II. K. 1955. Genetics and Metabolism. New York. 